Article

\title{
A highly stable and active mesoporous ruthenium catalyst for ammonia synthesis prepared by a $\mathrm{RuCl}_{3} / \mathrm{SiO}_{2}$-templated approach
}

\author{
Yaping Zhou a,b, Yongcheng Ma a, Guojun Lan a, Haodong Tanga, Wenfeng Han a, Huazhang Liu a, \\ Ying Li ${ }^{a}$,* \\ a Institute of Industry Catalysis, Zhejiang University of Technology, Hangzhou 310014, Zhejiang, China \\ b Sichuan Huadi Construction Engineering Co., Ltd., Chengdu 610081, Sichuan, China
}

\section{A R T I C L E I N F}

\section{Article history:}

Received 12 September 2018

Accepted 19 October 2018

Published 5 January 2019

\section{Keywords:}

Mesoporous carbon

Semi-embedded

$\mathrm{Ru} /$ Carbon catalyst

High dispersion

Ammonia synthesis

\begin{abstract}
A B S T R A C T
Molecular nitrogen is relatively inert and the activation of its triple bond is full of challenges and of significance. Hence, searching for an efficiently heterogeneous catalyst with high stability and dispersion is one of the important targets of chemical technology. Here, we report a Ba-K/Ru-MC catalyst with $\mathrm{Ru}$ particle size of $1.5-2.5 \mathrm{~nm}$ semi-embedded in a mesoporous $\mathrm{C}$ matrix and with dual promoters of $\mathrm{Ba}$ and $\mathrm{K}$ that exhibits a higher activity than the supported $\mathrm{Ba}-\mathrm{Ru}-\mathrm{K} / \mathrm{MC}$ catalyst, although both have similar metal particle sizes for ammonia synthesis. Further, the Ba-K/Ru-MC catalyst is more active than commercial fused Fe catalysts and supported Ru catalysts. Characterization techniques such as high-resolution transmission electron microscopy, $\mathrm{N}_{2}$ physisorption, CO chemisorption, and temperature-programmed reduction suggest that the $\mathrm{Ru}$ nanoparticles have strong interactions with the $\mathrm{C}$ matrix in $\mathrm{Ba}-\mathrm{K} / \mathrm{Ru}-\mathrm{MC}$, which may facilitate electron transport better than supported nanoparticles.
\end{abstract}

(C) 2019, Dalian Institute of Chemical Physics, Chinese Academy of Sciences. Published by Elsevier B.V. All rights reserved.

\section{Introduction}

Molecular nitrogen is relatively inert owing to the strength of its triple bond, its non-polarity, and high ionization potential. As a result, the fixation of atmospheric nitrogen to ammonia under mild conditions has remained a challenge to chemists and has been frequently studied as a prototype reaction for more than a century. Based on this reaction, many heterogeneous catalysis concepts have been developed [1]. Ru-based catalysts have been regarded as second-generation catalysts owing to their excellent performances and energy efficiencies at low temperatures and low pressures [2,3]. C materials have been extensively used as supports in heterogeneous catalysts because they satisfy the most desirable properties required of a suitable support, such as high chemical resistance, low cost, high surface area, and good electron and heat transport. C-supported $\mathrm{Ru}$ catalyst exhibits the highest performance among all types of supports that include $\mathrm{MgO}, \mathrm{BN}, \mathrm{Al}_{2} \mathrm{O}_{3}$, etc., and is the only catalyst that has been commercialized [4-7]. Although most scientists thought that methanation of the $\mathrm{C}$ support is inevitable, the BP company successfully solved this problem by using graphitized $\mathrm{C}$ as the support [8]. Aika et al. [9] reported that a moderate degree of methanation of $\mathrm{AC}$ support in Ba-promoted $\mathrm{Ru} / \mathrm{AC}$ catalysts increases the surface area and pore volume of the catalyst significantly, rather than destroying the porous structure. However, the methanation of a $\mathrm{C}$ support

\footnotetext{
* Corresponding author. Tel: +86-571-88320766; Fax: +86-571-88320259; E-mail: liying@zjut.edu.cn

This work was supported by the National Natural Science Foundation of China (20803064), and the Natural Science Foundation of Zhejiang Provence (LY17B030010).

DOI: 10.1016/S1872-2067(18)63192-4 | http://www.sciencedirect.com/science/journal/18722067 | Chin. J. Catal., Vol. 40, No. 1, January 2019
} 
might accelerate the growth of Ru particles, which can finally lead to a low activity. Thus, a respective control of the degree of methanation during the catalyst preparation and activation processes was thought to be very important for practical use of promoted $\mathrm{Ru} / \mathrm{C}$ catalysts.

With the development of nanocarbon materials with specific pore and framework structures, such as graphene and CNTs [10], the role of $C$ structure on the catalytic performance of C-supported metal clusters has gained much attention recently. There are several reports that discuss the effect of the interaction of the $\mathrm{C}$ support with $\mathrm{Ru}$ on the catalytic performances of $\mathrm{Ru}$ catalysts for ammonia synthesis. Bao et al. [11] reported a $\mathrm{Ru} / \mathrm{CNTs}$ catalyst, in which Ru nanoparticles (NPs) were confined inside CNTs; this catalyst displayed higher activities for $\mathrm{CO}$ hydrogenation and ammonia synthesis than these with $\mathrm{Ru}$ NPs outside the CNTs. This significant improvement has been attributed to be the uniquely confined environment that essentially shifts the volcano curves of the catalytic activities toward metals with higher confinement energies. Kitano et al. [12] reported a Ru-loaded electride $\left[\mathrm{Ca}_{24} \mathrm{Al}_{28} \mathrm{O}_{64}\right]^{4+}\left(\mathrm{e}^{-}\right)_{4}$ $\left(\mathrm{Ru} / \mathrm{C} 12 \mathrm{A7}: \mathrm{e}^{-}\right)$as an efficient catalyst for ammonia synthesis, which exhibits an activity that is an order of magnitude higher than those of other previously reported Ru-loaded catalysts and the reaction activation energy being almost half. Kinetic analysis with infrared spectroscopy reveals that C12A7: $\mathrm{e}^{-}$ markedly enhances $\mathrm{N}_{2}$ dissociation on $\mathrm{Ru}$ by the back donation of electrons and that the poisoning of Ru surfaces by $\mathrm{H}$ adatoms can be suppressed effectively because of the ability of C12A7: $\mathrm{e}^{-}$ to store $\mathrm{H}$ reversibly. All these reports indicate that new concepts in heterogeneous catalyst design are very important to fulfill the need for highly efficient catalysts for ammonia synthesis.

Recently, $\mathrm{Ru}$ NPs semi-embedded in a porous $\mathrm{C}$ matrix showed a promisingly higher performance for the hydrogenation of various reactants than its supported counterpart owing to the strong interaction between $\mathrm{Ru}$ and the $\mathrm{C}$ support [13-17]. Moreover, it is widely accepted that $\mathrm{N}_{2}$ dissociation is the rate-determining step [18] and that this step is sensitive to the electronic structure of a catalyst [19]. A higher electron density around metal centers facilitates $\mathrm{N}_{2}$ dissociation because it is an electrophilic process [20]. The bond of a $\mathrm{N}_{2}$ molecule is weakened by the incorporation of an electron into its antibonding orbital, which is evidenced by an increase in the work function. The strong interaction between $\mathrm{Ru}$ and the $\mathrm{C}$ support of the Ru-C catalyst with semi-embedded Ru nanoclusters will greatly improve the electron transport. Therefore, the Ru-C catalyst with semi-embedded Ru nanoclusters could be a more suitable candidate for ammonia synthesis.

Here, a Ba-K/Ru-MC catalyst with Ru particles embedded in mesoporous $\mathrm{C}$ materials and promoted with $\mathrm{Ba}$ and $\mathrm{K}$ was tested for ammonia synthesis and compared with its supported counterpart. The Ru-MC with homogenous Ru NPs embedded in $\mathrm{C}$ matrix was prepared via a sucrose-assisted in situ carbonization method and $\mathrm{Ba}$ and $\mathrm{K}$ were added by the impregnation method. It is generally accepted that dual promoters are necessary for ammonia synthesis, wherein $\mathrm{K}$ acts as an electron donor $[21,22]$ and $\mathrm{Ba}$ electrostatically modifies the potential around the B5 sites (electronic promotion), making them significantly more active for $\mathrm{N}_{2}$ dissociation [23]. Therefore, dual promoters are used to assist Ru-MC catalysts in ammonia synthesis.

\section{Experimental}

\subsection{Chemicals}

Commercialized nanosilica with particle size of $15 \pm 5 \mathrm{~nm}$ and surface area of $250 \pm 30 \mathrm{~m}^{2} / \mathrm{g}$ provided by Hangzhou Wanjing New Material Co., Ltd. was used as hard templates. The other reagents used were obtained from Shanghai Chemical Reagent Inc. of Chinese Medicine Group. All the materials were of analytical grade and were used without any further purification.

\subsection{Preparation of catalysts}

The method used for the synthesis of Ru-MC materials was the same as the nanoreplication method employed for Ru-OMC, which was described in our previously published papers $[13,15]$, except for the fact that $\mathrm{SiO}_{2}$ was used as the template instead of SBA-15. The typical method for the preparation of $\mathrm{Ru}-\mathrm{MC}$ can be described as follows. $1.0 \mathrm{~g}$ of $\mathrm{SiO}_{2}$ was impregnated with $2.5 \mathrm{ml}$ of an aqueous solution containing $0.1 \mathrm{~g}$ of ruthenium chloride hydrate. After being dried at $100{ }^{\circ} \mathrm{C}$ for $3 \mathrm{~h}$, $\mathrm{RuCl}_{3} / \mathrm{SiO}_{2}$ was obtained. A precursor solution containing sucrose (1.25 g) and oxalic acid ( $0.1 \mathrm{~g})$ in distilled water $(1.5 \mathrm{ml})$ was prepared, and the solution was allowed to infiltrate the mesopores of $\mathrm{RuCl}_{3} / \mathrm{SiO}_{2}$, which was then precarbonized at 100 ${ }^{\circ} \mathrm{C}$ for $6 \mathrm{~h}$ and at $160{ }^{\circ} \mathrm{C}$ for another $6 \mathrm{~h}$. Another precursor solution was prepared in the same fashion as the first step, except that the amount was two-thirds that of the first case. Further, the precarbonization process was the same as that employed in the first step. Then, the composite was carbonized at $850{ }^{\circ} \mathrm{C}$ for $3 \mathrm{~h}$ under $\mathrm{N}_{2}$ flow. Subsequently, the silica was removed by using a sodium hydroxide solution $\left(\mathrm{NaOH}: \mathrm{CH}_{3} \mathrm{CH}_{2} \mathrm{OH}: \mathrm{H}_{2} \mathrm{O}=1\right.$ : 22 : 44; molar ratio) at $70{ }^{\circ} \mathrm{C}$. Finally, Ru-MC was obtained after filtering and drying in air at $110{ }^{\circ} \mathrm{C}$ overnight. The method used for the synthesis of MC was the same as that used for the $\mathrm{Ru}-\mathrm{MC}$ described above, except that the $\mathrm{SiO}_{2}$ was directly impregnated with the sucrose solution.

The obtained Ru-MC was subsequently impregnated with $\mathrm{Ba}\left(\mathrm{NO}_{3}\right)_{2}$ and $\mathrm{KNO}_{3}$ salt solutions to introduce the respective promoters [24]. The obtained $\mathrm{Ba}-\mathrm{K} / \mathrm{Ru}-\mathrm{MC}$ catalyst was reduced under a flow of $\mathrm{H}_{2}$ at $400{ }^{\circ} \mathrm{C}$ for $4 \mathrm{~h}$. The nominal $\mathrm{Ba}$ and K loadings of the catalyst were $4 \%$ and $14 \%$, respectively.

The synthesized MC material was impregnated with $\mathrm{RuCl}_{3}$ solution for $12 \mathrm{~h}$ at room temperature. Then, the wet sample was precipitated by diluted ammonia solution at room temperature for $12 \mathrm{~h}$. After deposition, the solid was washed with deionized water several times at the desired temperature until no $\mathrm{Cl}^{-}$could be detected by $\mathrm{AgNO}_{3}$ solution, and dried at $110{ }^{\circ} \mathrm{C}$ for $12 \mathrm{~h}$. Finally, this sample $\mathrm{Ru} / \mathrm{MC}$ was reduced under a flow of $\mathrm{H}_{2}$ at $400^{\circ} \mathrm{C}$ for $4 \mathrm{~h}$.

The preparation procedures of $\mathrm{Ba}-\mathrm{Ru}-\mathrm{K} / \mathrm{MC}$ and 
$\mathrm{Ba}-\mathrm{Ru}-\mathrm{K} / \mathrm{AC}$ were the same as the method reported in our previous papers [7,24]. First, the MC or AC materials was impregnated with $\mathrm{Ba}\left(\mathrm{NO}_{3}\right)_{2}$ solution for $12 \mathrm{~h}$ at room temperature and dried at $110{ }^{\circ} \mathrm{C}$ for $12 \mathrm{~h}$. Subsequently, $\mathrm{RuCl}_{3}$ and $\mathrm{KNO}_{3}$ solutions were used for impregnation in the same manner as that described above. The catalysts were reduced under a flow of $\mathrm{H}_{2}$ at $400{ }^{\circ} \mathrm{C}$ for $4 \mathrm{~h}$. The nominal $\mathrm{Ba}, \mathrm{Ru}$, and $\mathrm{K}$ loadings of the catalysts were $4 \%, 4 \%$, and $14 \%$, respectively. The details of the preparation process of the various catalysts are given in Scheme 1.

\subsection{Activity measurements}

Ammonia synthesis reactions over the samples were carried out in a fixed-bed reactor having an inner diameter of $14 \mathrm{~mm}$ at the temperature of $375-450{ }^{\circ} \mathrm{C}$, space velocity of $10000 \mathrm{~h}^{-1}$, and pressure of $10 \mathrm{MPa}$. The catalyst bed was diluted with quartz $(1.0-2.0 \mathrm{~mm})$ that was loaded in the isothermal zone of the reactor, and both ends of the catalyst bed were also filled with quartz to prevent the synthesis gas from channeling. The catalysts were activated by the synthesis gas at the pressure of $5.0 \mathrm{MPa}$ and space velocity of $30000 \mathrm{~h}^{-1}$ at $400,425,450$, and $475^{\circ} \mathrm{C}$ for $4,8,8$, and $4 \mathrm{~h}$, respectively. After the activation, the temperature was lowered to $400{ }^{\circ} \mathrm{C}$ and the initial activity was measured. Then, the temperature was increased to $475^{\circ} \mathrm{C}$ for $16 \mathrm{~h}$, with the space velocity being $30000 \mathrm{~h}^{-1}$ and pressure 5 $\mathrm{MPa}$, in order to test the stability of the catalysts. After the thermal resistance test, the final activities were measured. The concentration of ammonia in the exit gas of the reactor under the given conditions was measured by the method of sulfuric acid neutralization.

The mixture of $\mathrm{N}_{2}$ and $\mathrm{H}_{2}$ was derived from the dissociation of ammonia, with deep removal of $\mathrm{H}_{2} \mathrm{O}, \mathrm{CO}, \mathrm{CO}_{2}$, and residual $\mathrm{NH}_{3}$ over $\mathrm{Pd}, 13 \mathrm{X}$, and $5 \mathrm{~A}$ molecular sieves.

The mass reaction rate of ammonia synthesis was calculated from the following equation [24]:

$$
r_{m}=\frac{S_{v} V_{c}}{22.4 W_{c}} \times \frac{\varphi_{\mathrm{NH}_{3}}}{1+\varphi_{\mathrm{NH}_{3}}}
$$

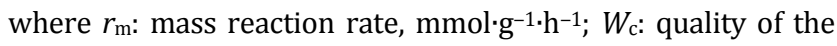
catalyst, g; $V_{\mathrm{c}}$ : volume of the catalyst, $\mathrm{cm}^{3} ; S_{\mathrm{v}}$ : space velocity of the reaction, $\mathrm{h}^{-1} ; \varphi_{\mathrm{NH} 3}$ : concentration of ammonia in the exit gas of the reactor, $\operatorname{vol} \%$.

\subsection{Characterization}

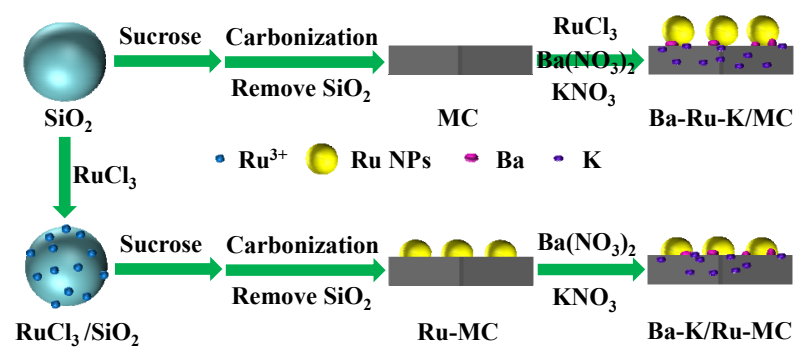

Scheme. 1. Synthesis of $\mathrm{Ba}-\mathrm{Ru}-\mathrm{K} / \mathrm{MC}$ and $\mathrm{Ba}-\mathrm{K} / \mathrm{Ru}-\mathrm{MC}$ catalysts.
Nitrogen sorption isotherms were determined at $-196^{\circ} \mathrm{C}$ by using a Quantachrome Autosorb-IQ instrument in static measurement mode. Before the measurement, the samples were degassed at $240{ }^{\circ} \mathrm{C}$ for $3 \mathrm{~h}$. The surface area of the $\mathrm{C}$ was calculated from the adsorption isotherms by the MultiPoint BET method. The pore size distribution of the supports was determined by the BJH method based on the desorption branch.

High resolution transmission electron microscopy (HRTEM) was performed on a TECNAI G2 F30 S-TWIN FEI Tecnai electron microscope operated at $300 \mathrm{kV}$, with a field emission gun acting as the source of electrons. The samples were mounted and ultrasonically dispersed in ethanol, and then, a few droplets of the suspension were deposited on a $\mathrm{Cu}$ grid coated with a holey $\mathrm{C}$ film, followed by drying under ambient conditions. The particle size distribution was determined for two hundred particles, and the average particle size was calculated based on the following equation:

$$
d=\frac{\sum n_{i} d_{i}^{3}}{\sum n_{i} d_{i}^{2}}
$$

Raman spectra were collected on a T6400 Raman spectrometer. An excitation laser line of wavelength $325 \mathrm{~nm}$ was used. The laser power impinging on the sample was less than $2.0 \mathrm{~mW}$. The spectral resolution was estimated to be $4.0 \mathrm{~cm}^{-1}$.

CO chemisorption experiment was carried out at $40{ }^{\circ} \mathrm{C}$ on a Quantachrome Autosorb-IQ Chemisorb apparatus. Prior to the measurements, the prereduced catalysts were further reduced in situ for $4 \mathrm{~h}$ at $400{ }^{\circ} \mathrm{C}$ in $\mathrm{H}_{2}$. The metal dispersion and particle size were also estimated based on the assumption of spherical geometry of the particles and adsorption stoichiometry of one $\mathrm{H}$ atom and one $\mathrm{CO}$ molecule on one surface Ru atom. The average Ru particle size, $d$, was calculated from $d \times D=\mathrm{M} \times 6 \times$ $\rho_{\text {site }} \div\left(\rho_{\text {metal }} \times \mathrm{N}\right)$, where $D$ is the dispersion, $M$ is the molecular weight (for $\mathrm{Ru}$, it is $101.07 \mathrm{~g} / \mathrm{mol}$ ), $\rho_{\text {site }}$ is the Ru surface site density (16.3 atoms $/ \mathrm{nm}^{2}$ ), $\rho_{\text {metal }}$ is the metal density $(12.3$ $\mathrm{g} / \mathrm{cm}^{3}$ for $\left.\mathrm{Ru}\right)$, and $\mathrm{N}$ is the Avogadro number $\left(6.022 \times 10^{23}\right.$ $\left.\mathrm{mol}^{-1}\right)$; the relation thus reduced to $d=1 \cdot 33 / \mathrm{D}(\mathrm{nm})[10,14]$.

$\mathrm{H}_{2}$-temperature-programmed reduction analyses ( $\mathrm{H}_{2}$-TPR-MS) were carried out by using a self-made TPD/TPR instrument. The mass spectra were collected by an online Hiden gas analyzer (QIC 20). Prior to the analysis, the sample (ca. $50 \mathrm{mg}$ ) was placed in a fixed bed of a U-shaped quartz tube located inside an electrical furnace and dehydrated at $110{ }^{\circ} \mathrm{C}$ for $0.5 \mathrm{~h}$ under flowing $\mathrm{Ar}$. Then, the temperature was increased at a rate of $10{ }^{\circ} \mathrm{C} / \mathrm{min}$ from 50 up to $900{ }^{\circ} \mathrm{C}$ under a flow of $5 \% \mathrm{H}_{2} / \mathrm{Ar}(40 \mathrm{ml} / \mathrm{min})$. The following mass signals were monitored simultaneously by using a quadrupole mass spectrometer: $m / e=2,15,16,17,18,28$, and $44 \mathrm{amu}$.

\section{Results and discussion}

\subsection{Structural properties of Ru-MC and various catalysts}

Table 1 lists the physical properties of MC, Ru-MC, Ru/MC, and the other catalysts used for ammonia synthesis. The specific surface area of MC is $1038 \mathrm{~m}^{2} / \mathrm{g}$, and the pore size is around $14.8 \mathrm{~nm}$, which is a good replication of the size of $\mathrm{SiO}_{2}$ 
Table 1

Structural properties of mesoporous $\mathrm{C}$ and the various catalysts used for ammonia synthesis.

\begin{tabular}{|c|c|c|c|c|c|c|}
\hline Catalyst & $\begin{array}{c}\text { Total surface area } \\
\left(\mathrm{m}^{2} / \mathrm{g}\right)\end{array}$ & $\begin{array}{c}\text { Meso. surface area } \\
\left(\mathrm{m}^{2} / \mathrm{g}\right)\end{array}$ & $\begin{array}{c}\text { Total pore volume } \\
\left(\mathrm{cm}^{3} / \mathrm{g}\right)\end{array}$ & $\begin{array}{c}\text { Meso pore volume } \\
\left(\mathrm{cm}^{3} / \mathrm{g}\right)\end{array}$ & $\begin{array}{l}\text { Pore diameter* } \\
(\mathrm{nm})\end{array}$ & $I_{\mathrm{D}} / I_{\mathrm{G}}$ \\
\hline MC & 1038 & 842 & 2.12 & 2.02 & 14.8 & 0.84 \\
\hline $\mathrm{AC}$ & 1779 & 319 & 0.81 & 0.18 & $<2$ & 0.89 \\
\hline $\mathrm{Ru} / \mathrm{MC}$ & 588 & 487 & 1.36 & 1.31 & 12.7 & 0.84 \\
\hline Ru-MC & 881 & 545 & 1.32 & 1.17 & 13.9 & 0.83 \\
\hline Ba-Ru-K/MC & 295 & 277 & 0.78 & 0.77 & 11.6 & 0.89 \\
\hline Ba-K/Ru-MC & 382 & 293 & 0.73 & 0.69 & 12.9 & 0.86 \\
\hline Ba-Ru-K/AC & 438 & 101 & 0.19 & 0.06 & $<2$ & 0.91 \\
\hline
\end{tabular}

${ }^{*}$ Calculated from the desorption branch of the isotherm according to the BJH method.

particles. The specific surface area of Ru-MC is $881 \mathrm{~m}^{2} / \mathrm{g}$, and the pore size is around $13.9 \mathrm{~nm}$. The incorporation of $\mathrm{Ru}$ decreases the surface area of MC by ca. $15 \%$, with the pore size decreasing by about $1 \mathrm{~nm}$. This may indicate that the existence of $\mathrm{Ru}$ affects the formation of the mesoporous $\mathrm{C}$ structure. The $\mathrm{N}_{2}$ adsorption-desorption isotherms and the pore size distributions of MC, Ru-MC, Ru/MC, Ba-Ru-K/MC, and Ba-K/Ru-MC are given in Fig. 1. All the samples reveal the typical type IV adsorption isotherm with a hysteresis loop at a high relative pressure range 0.7-1.0 for mesoporous materials with large pores. The sharpness of the peaks in the pore size distribution curves indicate the narrowness of the size distributions of all the samples. Although the surface areas of $\mathrm{Ru} / \mathrm{MC}$ and $\mathrm{Ba}-\mathrm{Ru}-\mathrm{K} / \mathrm{MC}$ decreased from 1038 to 588 and $295 \mathrm{~m}^{2} / \mathrm{g}$, respectively; the shapes of the $\mathrm{N}_{2}$ isotherms do not change much. The pore size decreased to 12.7 and $11.6 \mathrm{~nm}$ from $14.8 \mathrm{~nm}$. This may indicate that $\mathrm{Ru}$ and the promoters are deposited in the mesopores of the $\mathrm{C}$ supports and that the mesopores are not blocked. The surface area of Ba-K/Ru-MC is $382 \mathrm{~m}^{2} / \mathrm{g}$, and the decreasing trend is much lower compared to that of the $\mathrm{Ba}-\mathrm{Ru}-\mathrm{K} / \mathrm{MC}$ catalyst. This result indicates that the relatively larger pores of the $\mathrm{MC}$ prepared by using $\mathrm{SiO}_{2}$ are beneficial for catalysts with high loadings of multiple promoters.

The structure of the obtained MC and Ru-MC was characterized by Raman spectroscopy. The Raman spectra of the MC, $\mathrm{Ru}-\mathrm{MC}, \mathrm{Ru} / \mathrm{MC}$, and AC are given in Fig. 2. Two bands at 1347 and $1590 \mathrm{~cm}^{-1}$ were observed. The band at $1347 \mathrm{~cm}^{-1}$ is referred to as the $\mathrm{D}$ band and is attributed to the vibrations of $\mathrm{C}$

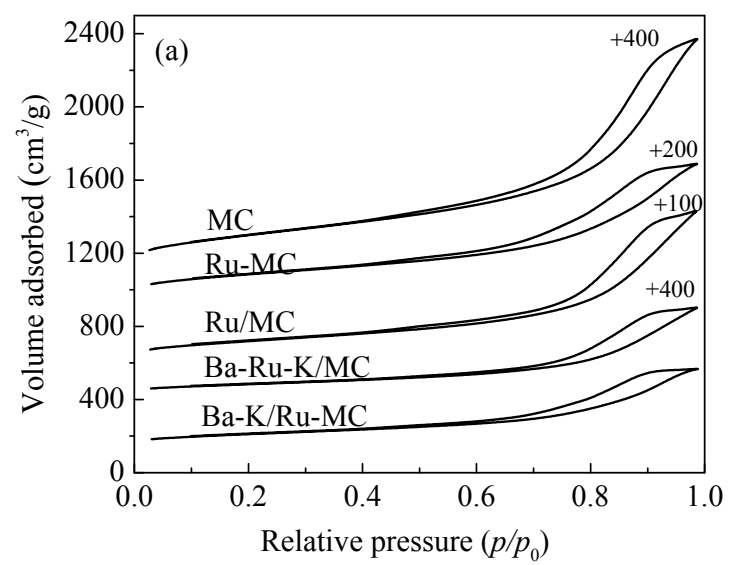

atoms with dangling bonds in the planar terminations of a disordered graphite-like structure. The band around $1590 \mathrm{~cm}^{-1}$ is referred to as the $\mathrm{G}$ band, which corresponds to the $\mathrm{E} 2 \mathrm{~g}$ vibrations (aromatic $\mathrm{C}=\mathrm{C}$; $s p^{2} \mathrm{C}$ ) [25]. The intensity ratio $I_{\mathrm{D}} / I_{\mathrm{G}}$ reflects the degree of graphitization, with a decrease in its value suggesting that the degree of graphitization has increased. The $I_{\mathrm{D}} / I_{\mathrm{G}}$ values (Table 1 ) of all the samples are almost the same, ca. 0.83-0.84. This value is typical of $C$ materials with an amorphous framework. On the other hand, the $I_{\mathrm{D}} / I_{\mathrm{G}}$ values of Ba-Ru-K/MC and Ba-K/Ru-MC are increased to about 0.89 and 0.86 , respectively, which could be caused by the activation of the $\mathrm{C}$ support during the reduction of the catalysts after loading $\mathrm{Ba}\left(\mathrm{NO}_{3}\right)_{2}$ and $\mathrm{KNO}_{3}$ to the as-prepared $\mathrm{MC}$ and $\mathrm{Ru}-\mathrm{MC}$ [31]. The $I_{\mathrm{D}} / I_{\mathrm{G}}$ value of $\mathrm{MC}$ is lower than that of $\mathrm{AC}$, which is 0.89 , indicating that the degree of graphitization of MC is higher than that of AC. Moreover, the emergence of the $\mathrm{G}^{\prime}$-band around $2880 \mathrm{~cm}^{-1}$ indicates the formation of a-few-layers structured graphitic C [26,27]. This band is more obvious for the MC and Ru-MC samples than for AC. This result may indicate that the MC and Ru-MC synthesized via sucrose contain a-few-layers structured graphitic $\mathrm{C}$. The pore and framework structures of MC and Ru-MC were characterized via HRTEM, and the results are given in Fig. 3. As discussed above, the pore structures of MC, Ru-MC, and Ru/MC are similar. The typical TEM and HRTEM images of MC are given in Fig. 3(a) and Fig. 3(b), respectively. It can be observed that the mesopores are disordered, with pore sizes in the range $10-20 \mathrm{~nm}$, and the $\mathrm{C}$ wall is quite thin compared with that of AC (Fig. 3a). A few layers of

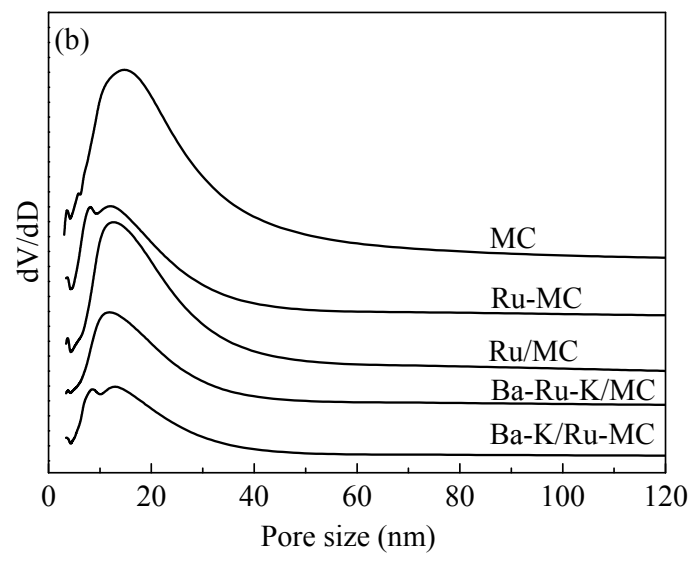

Fig. 1. $\mathrm{N}_{2}$ adsorption-desorption isotherms (a) and pore size distribution curves (b) of MC and various catalysts. 


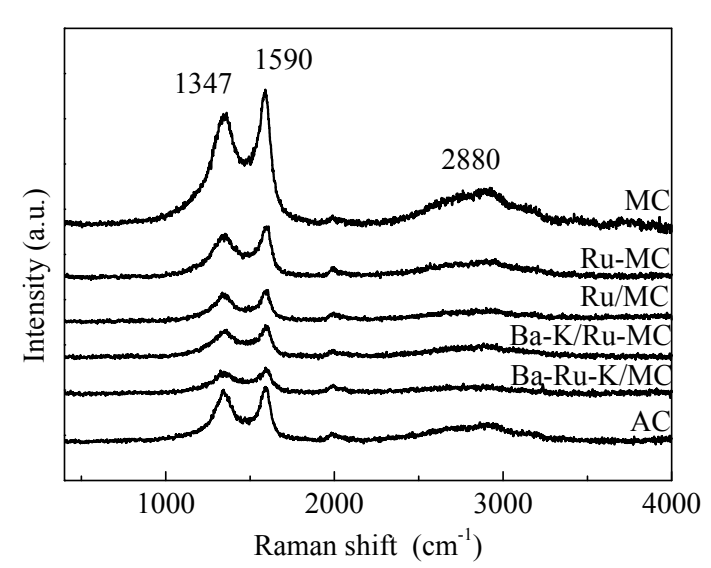

Fig. 2. Raman spectra of $M C, A C, R u-M C, R u / M C, B a-R u-K / M C$, and $\mathrm{Ba}-\mathrm{K} / \mathrm{Ru}-\mathrm{MC}$.

the graphitic structure can also be observed in the HRTEM image.

\subsection{Status of Ru NPs in various catalysts}

The status of Ru NPs was examined by HRTEM. It is known that the Ru NPs supported on AC are difficult to be observed by TEM owing to the influence of $\mathrm{C}$, especially in the cases of catalysts with small nanoparticles (less than $2 \mathrm{~nm}$ ). The HRTEM images of Ru-MC at different resolutions are given in Fig. $3(\mathrm{~d}-\mathrm{f})$. For a comparison, the TEM image of $\mathrm{Ru} / \mathrm{MC}$ is provided in Fig. 3(c). The black dots distributed in the HRTEM images are $\mathrm{Ru}$ particles. It can be seen that the Ru NPs both in Ru-MC and $\mathrm{Ru} / \mathrm{MC}$ are uniformly distributed on the supports and no aggregation is observed. The particle size distributions of Ru-MC
(Fig. 3(e)) and Ru/MC (Fig. 3(c)) are both in the range 1.5-2.5 $\mathrm{nm}$, and the average particle size is ca. $2 \mathrm{~nm}$. Fig. S2 shows the STEM images and particle size distributions of Ru NPs for $\mathrm{Ba}-\mathrm{K} / \mathrm{Ru}-\mathrm{MC}$ and $\mathrm{Ba}-\mathrm{Ru}-\mathrm{K} / \mathrm{MC}$ catalysts. It can be seen that the particle size distributions of the abovementioned catalysts are relatively narrow. The average particle size of $\mathrm{Ba}-\mathrm{K} / \mathrm{Ru}-\mathrm{MC}$ is $2.2 \mathrm{~nm}$, whereas that of Ba-Ru-K/MC is $2.3 \mathrm{~nm}$ (Table 2), which is almost the same as those of the $\mathrm{Ru}-\mathrm{MC}$ and $\mathrm{Ru} / \mathrm{MC}$ samples. As is known, ammonia synthesis is a structure-sensitive reaction. The most active sites for $\mathrm{N}_{2}$ dissociation and ammonia synthesis are ensembles of five Ru atoms, named B5-type sites [28]. Jacobsen et al. [19] reported that the B5 sites are only present on $\mathrm{Ru}$ particles larger than $0.7 \mathrm{~nm}$. The probability of existence of B5 sites is maximum for Ru particles of size 1.8-2.5 $\mathrm{nm}$, and monotonically decreases for particles larger than 2.5 $\mathrm{nm}$. Therefore, if only the particle size is considered, both the $\mathrm{Ba}-\mathrm{K} / \mathrm{Ru}-\mathrm{MC}$ and $\mathrm{Ba}-\mathrm{Ru}-\mathrm{K} / \mathrm{MC}$ catalysts with Ru particles in the size range $1.5-2.5 \mathrm{~nm}$ are appropriate for forming more active B5-type sites. From Fig. 3(f), it can be seen that most of the Ru NPs on the Ru-MC catalyst are semi-embedded in the mesoporous $\mathrm{C}$ framework. This phenomenon has been observed in $\mathrm{Ru}-\mathrm{OMC}$ catalysts as well and has been fully discussed [13-15]. Uniform Ru NPs were obtained by thermal reduction; the consumption of $\mathrm{C}$ during the reduction of $\mathrm{Ru}^{3+}$ to $\mathrm{Ru}$ enables the $\mathrm{Ru}$ NPs to sit in or semi-embed in the $C$ matrix. To estimate the degree of embedding of the Ru NPs, the dispersion of Ru particles was characterized by $\mathrm{CO}$ chemisorption for the Ru-MC and $\mathrm{Ru} / \mathrm{MC}$ catalysts, and the results are included in Table 2 . The dispersion of $\mathrm{Ru}$ for $\mathrm{Ru}-\mathrm{MC}$ is $35.2 \%$, while it is $65.6 \%$ for $\mathrm{Ru} / \mathrm{MC}$, according to the $\mathrm{CO}$ chemisorption measurements. The $\mathrm{CO}$ monolayer uptakes of Ru-MC and $\mathrm{Ru} / \mathrm{MC}$ are 138.4 and $258.0 \mu \mathrm{mol} / \mathrm{g}$, respectively. Based on the chemisorption data and assuming the adsorption of one $\mathrm{CO}$ per metal atom, one can
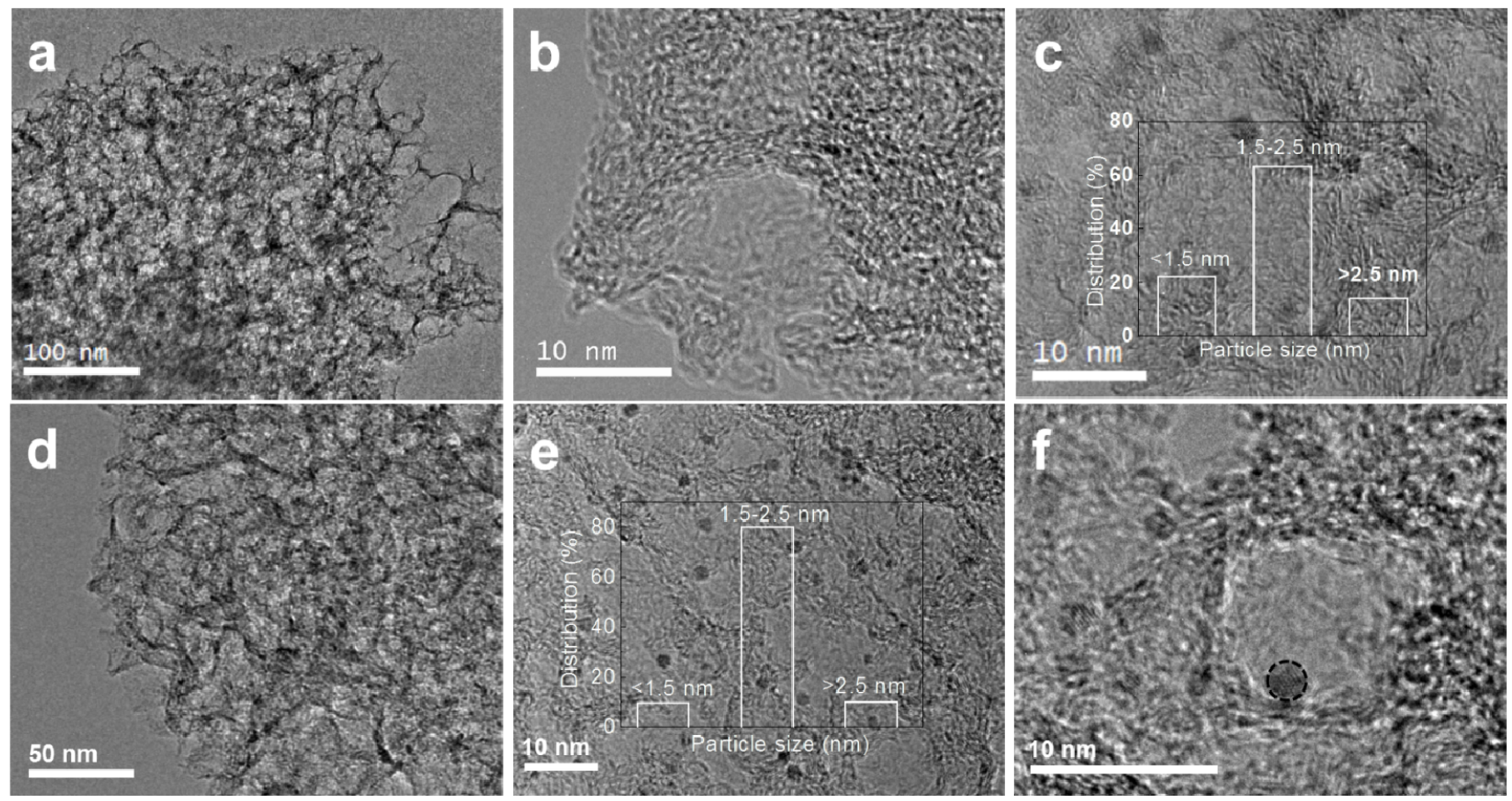

Fig. 3. TEM images of MC (a,b), Ru/MC (c), and Ru-MC (d-f) and particle size distributions of Ru/MC (c) and Ru-MC (e) catalysts. 
Table 2

Dispersion and particle size of Ru NPs, as determined by CO chemisorption and TEM, for Ru-MC and Ru/MC.

\begin{tabular}{|c|c|c|c|c|c|c|c|c|}
\hline \multirow{2}{*}{ Catalyst } & \multirow{2}{*}{$\begin{array}{c}\mathrm{Ru}^{\mathrm{a}} \\
\text { (wt\%) }\end{array}$} & \multicolumn{4}{|c|}{ CO chemisorption } & \multicolumn{2}{|c|}{ TEM } & \multirow{2}{*}{$D_{\text {em }}{ }^{\mathrm{b}}(\%)$} \\
\hline & & CO uptake $(\mu \mathrm{mol} / \mathrm{g})$ & Ru S.A. $\left(\mathrm{m}^{2} / \mathrm{g}\right)$ & Dispersion (\%) & Particle size $(\mathrm{nm})$ & Dispersion (\%) & Particle size (nm) & \\
\hline Ru-MC & 2.52 & 138.4 & 5.1 & 35.2 & 3.8 & 66.5 & 2.0 & 47.1 \\
\hline $\mathrm{Ru} / \mathrm{MC}$ & 2.66 & 258.0 & 9.5 & 65.6 & 2.0 & 66.5 & 2.0 & 1.4 \\
\hline Ba-K/Ru-MC & 2.45 & 142.3 & 5.3 & 36.2 & 3.7 & 60.5 & 2.2 & 40.2 \\
\hline Ba-Ru-K/MC & 2.30 & 115.5 & 4.3 & 29.4 & 4.6 & 57.8 & 2.3 & 49.1 \\
\hline
\end{tabular}

a Determined via EDS

${ }^{\mathrm{b}} D_{\mathrm{em}}=\left(1-N_{\mathrm{s}} \div N_{\mathrm{c}}\right) \times 100 \%$, where $N_{\mathrm{s}}$ refers to the number of metal atoms present on the surface, as measured by CO chemisorption, and $N_{\mathrm{c}}$ refers to the number of metal atoms present on the surface, based on the average crystallite size determined by HRTEM.

estimate the exposed surface area of the metal catalysts. It can be seen that the exposed active Ru surface areas are 5.1 and 9.5 $\mathrm{m}^{2} / \mathrm{g}$. On the other hand, the Ru NPs sizes of Ru-MC and Ru/MC obtained by HRTEM are almost the same. This indicates that a fraction of the Ru NPs are embedded in the $\mathrm{C}$ matrix. The degree of embedding was calculated by the formula $D_{\text {embedding }}=(1$ $-\mathrm{N}_{\mathrm{s}} \div \mathrm{N}_{\mathrm{c}}$ ) $\times 100 \%$, where $\mathrm{N}_{\mathrm{s}}$ refers to the number of metal atoms present on the surface, as measured by $\mathrm{CO}$ chemisorption, and $N_{c}$ refers to the number of metal atoms present on the surface, based on the average crystallite size determined by HRTEM. The estimated degrees of embedding of the Ru NPs are given in Table 2. It can be seen that the degree of embedding of $\mathrm{Ru}-\mathrm{MC}$ is $47.1 \%$, whereas it is $1.4 \%$ for $\mathrm{Ru} / \mathrm{MC}$, thus indicating that the Ru NPs of Ru-MC are semi-embedded in the C structure. However, the dispersions of $\mathrm{Ru}$ in the $\mathrm{Ba}-\mathrm{K} / \mathrm{Ru}-\mathrm{MC}$ and $\mathrm{Ba}-\mathrm{Ru}-\mathrm{K} / \mathrm{MC}$ catalysts are $36.2 \%$ and $29.4 \%$, respectively. This may be due to the addition of promoters, which cover some of the Ru NPs and, thereby, affect the dispersion of the catalysts. It can be considered that the degrees of embedding of $\mathrm{Ba}-\mathrm{K} / \mathrm{Ru}-\mathrm{MC}$ and $\mathrm{Ba}-\mathrm{Ru}-\mathrm{K} / \mathrm{MC}$ do not represent the state of existence of the Ru NPs on the $C$ surface.

\subsection{Performances of various catalysts for ammonia synthesis}

It is generally accepted that both $\mathrm{Ba}$ and $\mathrm{K}$ are necessary for ammonia synthesis, as $\mathrm{K}$ acts as an electron donor [21,29] and

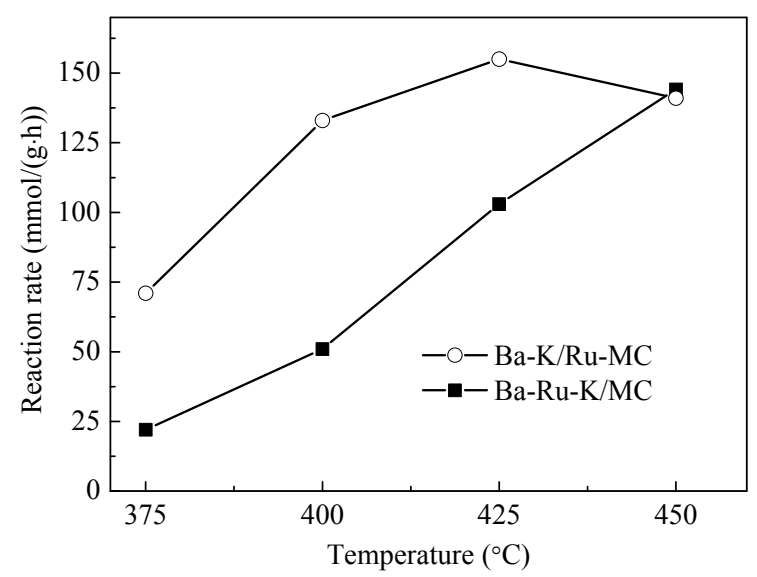

Fig. 4. Reaction rates for ammonia synthesis over $\mathrm{Ba}-\mathrm{K} / \mathrm{Ru}-\mathrm{MC}$ and $\mathrm{Ba}-\mathrm{Ru}-\mathrm{K} / \mathrm{MC}$ at different temperatures. Reaction conditions: $10 \mathrm{MPa}$, $10000 \mathrm{~h}^{-1}$.
Ba electrostatically modifies the potential around the B5 sites (electronic promotion), rendering them significantly more active for $\mathrm{N}_{2}$ dissociation [23]. Therefore, $\mathrm{Ru}-\mathrm{MC}$ and $\mathrm{Ru} / \mathrm{MC}$ were impregnated with $\mathrm{Ba}\left(\mathrm{NO}_{3}\right)_{2}$ and $\mathrm{KNO}_{3}$ as promoters. The catalytic performances of $\mathrm{Ba}-\mathrm{K} / \mathrm{Ru}-\mathrm{MC}$ and $\mathrm{Ba}-\mathrm{Ru}-\mathrm{K} / \mathrm{MC}$ were investigated at various temperatures in a four-tube reactor under $10 \mathrm{MPa}$, and the results are given in Fig. 4. It is obvious that the activity of $\mathrm{Ba}-\mathrm{K} / \mathrm{Ru}-\mathrm{MC}$ at $375^{\circ} \mathrm{C}$ is almost twice that of $\mathrm{Ba}-\mathrm{Ru}-\mathrm{K} / \mathrm{MC}$. The reaction rates observed at $450{ }^{\circ} \mathrm{C}$ are the same because the ammonia synthesis process has reached thermodynamic equilibrium. The best catalyst always performs well at lower temperatures. This indicated that Ba-K/Ru-MC with semi-embedded $\mathrm{Ru}$ NPs is much more active than Ba-Ru-K/MC.

\subsection{Characterizations and stability test of $B a-K / R u-M C$}

To understand the high performance of $\mathrm{Ba}-\mathrm{K} / \mathrm{Ru}-\mathrm{MC}$ and clarify the interaction between the Ru NPs and the mesoporous $\mathrm{C}$, a series of temperature-programmed treatments of the Ru-MC, Ru/MC, Ba-K/Ru-MC, and Ba-Ru-K/MC samples were performed under $5 \% \mathrm{H}_{2} / \mathrm{Ar}$. $\mathrm{H}_{2}$-TPR patterns were obtained with a mass spectrometer. As is known, the presence of $\mathrm{Ru}$ metal can catalyze the methanation of the $\mathrm{C}$ support in the range $300-500{ }^{\circ} \mathrm{C}$. Therefore, methane signals were detected together with the $\mathrm{H}_{2}$ signals. The $\mathrm{H}_{2}$-TPR profiles with the $\mathrm{H}_{2}$ and methane signals are provided in Figs. 5(a) and (b). It can be seen that the peaks corresponding to the consumption of $\mathrm{H}_{2}$ are totally different for the Ru-MC and $\mathrm{Ru} / \mathrm{MC}$ samples. Compared to the methanation peaks of the Ru/MC samples, the methane peaks of the Ru-MC samples are observed at relatively lower temperatures. This observation can be interpreted as easier methanation of the $\mathrm{C}$ support in the embedded $\mathrm{Ru}-\mathrm{MC}$ catalysts than in the supported $\mathrm{Ru} / \mathrm{MC}$ catalysts, owing to the strong interaction between $\mathrm{Ru}$ and the $\mathrm{C}$ support. This result is similar to those of $\mathrm{Ru}-\mathrm{OMC}$ and $\mathrm{Ru} / \mathrm{OMC}$ [15]. Otherwise, the adsorption properties of $\mathrm{H}_{2}$ play an important role in ammonia synthesis. Fig. $\mathrm{S} 1$ gives the $\mathrm{H}_{2}$-TPD profiles of the $\mathrm{Ba}-\mathrm{K} / \mathrm{Ru}-\mathrm{MC}$ and Ba-Ru-K/MC catalysts. Two $\mathrm{H}_{2}$ desorption peaks at about 140 and $450{ }^{\circ} \mathrm{C}$ could be observed in the Ba-K/Ru-MC, and the total amount of desorbed $\mathrm{H}_{2}$ for $\mathrm{Ba}-\mathrm{K} / \mathrm{Ru}-\mathrm{MC}$ is much higher than that for $\mathrm{Ba}-\mathrm{Ru}-\mathrm{K} / \mathrm{MC}$. The trend could explain the activities of these catalysts for ammonia synthesis. On the other hand, the methanation of $\mathrm{C}$ in the dual-promoted $\mathrm{Ba}-\mathrm{Ru}-\mathrm{K} / \mathrm{MC}$ occurs at 320 and $450{ }^{\circ} \mathrm{C}$, and the temperature is much lower than that 

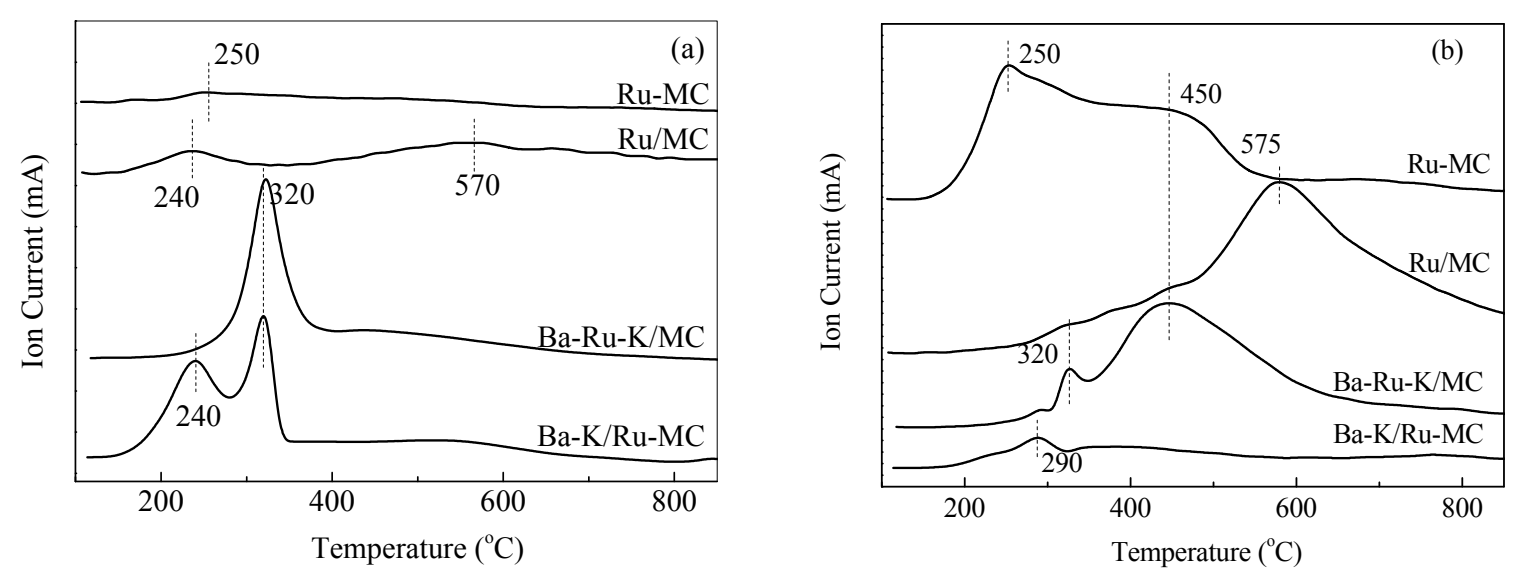

Fig. 5. $\mathrm{H}_{2}$-TPR profiles of Ru-MC, $\mathrm{Ru} / \mathrm{MC}, \mathrm{Ba}-\mathrm{K} / \mathrm{Ru}-\mathrm{MC}$, and Ba-Ru-K/MC catalysts. (a) signal of $\mathrm{H}_{2}, m / e=2$; (b) signal of $\mathrm{CH}_{4}, m / e=15$.

for $\mathrm{Ru} / \mathrm{MC}$. However, it is interesting to observe that the methanation of $\mathrm{C}$ was greatly suppressed for the Ba-K/Ru-MC catalyst, compared with the Ba-Ru-K/MC catalyst. The methanation may result in a weight loss of the $\mathrm{C}$ support, which can affect the stability of the catalyst.

To further verify the degrees of methanation of Ba-K/Ru-MC and $\mathrm{Ba}-\mathrm{Ru}-\mathrm{K} / \mathrm{MC}$, the catalysts were tested by keeping them under $\mathrm{H}_{2}$ atmosphere at $400{ }^{\circ} \mathrm{C}$ for more than 15 h. Fig. 6 shows the methanation signals for the Ba-K/Ru-MC and Ba-Ru-K/MC catalysts when the temperature first increased to $400{ }^{\circ} \mathrm{C}$ and was then kept constant (at $400{ }^{\circ} \mathrm{C}$ ) for more than $15 \mathrm{~h}$. The methanation resulted in two peaks being observed in the temperature range $100-400{ }^{\circ} \mathrm{C}$. The first peak appears at $320^{\circ} \mathrm{C}$ for $\mathrm{Ba}-\mathrm{Ru}-\mathrm{K} / \mathrm{MC}$ and $290{ }^{\circ} \mathrm{C}$ for $\mathrm{Ba}-\mathrm{K} / \mathrm{Ru}-\mathrm{MC}$ catalyst. The areas under the methanation peaks are much lower for Ba-K/Ru-MC compared to Ba-Ru-K/MC. The methanation of $\mathrm{C}$ only occurs at the start of the reaction, and the peaks significantly decreased in intensity to zero in $4 \mathrm{~h}$. Therefore, the lives of the catalysts may not be affected by the methanation process. This could because the surfaces of the catalysts contain small amounts of unstable $\mathrm{C}$, which is beneficial for methanation at low temper-

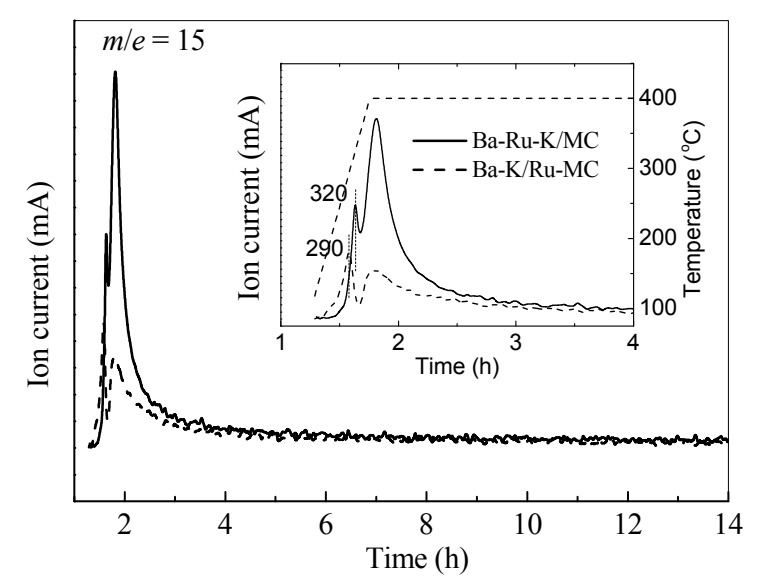

Fig. 6. $\mathrm{H}_{2}$-temperature-programmed methanation of $\mathrm{Ba}-\mathrm{K} / \mathrm{Ru}-\mathrm{MC}$ and $\mathrm{Ba}-\mathrm{Ru}-\mathrm{K} / \mathrm{MC}$ catalysts as functions of reaction time. atures. It is well known that methane can be a source of $\mathrm{C}$ for the preparation of nanocarbons over Ru catalysts [30]. Therefore, some methane would be consumed to form deposited C, and thus, the formation of methane has a negligible influence on the activities of catalysts [31,32].

To test the stability of the $\mathrm{Ba}-\mathrm{K} / \mathrm{Ru}-\mathrm{MC}$, a thermal resistance experiment was carried at $475^{\circ} \mathrm{C}$ for $16 \mathrm{~h}$ at $5 \mathrm{MPa}$, with space velocity being $30000 \mathrm{~h}^{-1}$, and the catalytic performance of Ba-K/Ru-MC before and after the test is shown in Fig. 7. Fig. S3 shows the ammonia synthesis rates as functions of the time on stream. The catalytic performance of $\mathrm{Ba}-\mathrm{K} / \mathrm{Ru}-\mathrm{MC}$ is improved, instead of it being deactivated. This indicates that the catalysts are stable under high pressures and temperatures. The HRTEM images of $\mathrm{Ba}-\mathrm{K} / \mathrm{Ru}-\mathrm{MC}$ before and after ammonia synthesis are shown in Fig. 8. It is seen that the Ru NPs after ammonia synthesis maintain almost the same size as fresh Ba-K/Ru-MC. It indicates that the semi-embedded catalyst $\mathrm{Ba}-\mathrm{K} / \mathrm{Ru}-\mathrm{MC}$ is stable with respect to the Ru NPs. This can be explained by the much stronger interaction between $\mathrm{Ru}$ and $\mathrm{C}$ in the case of a semi-embedded structure.

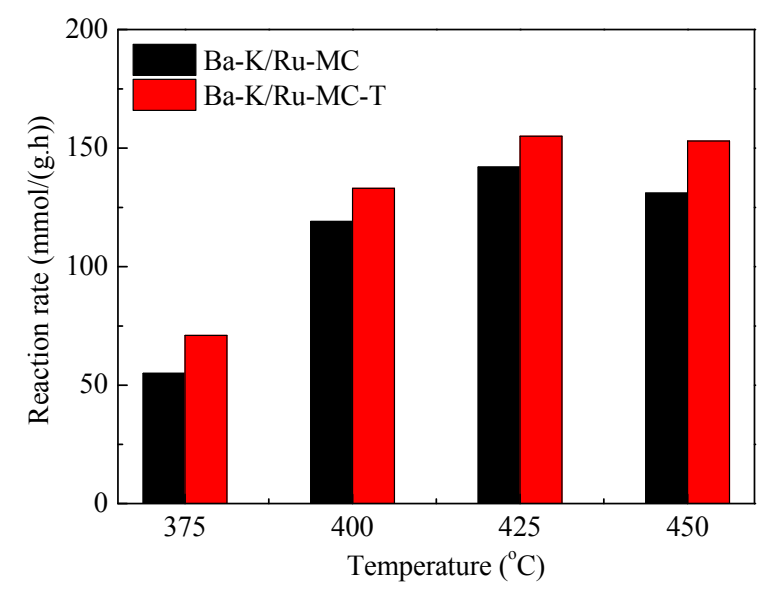

Fig. 7. Reaction rates for ammonia synthesis over Ba-K/Ru-MC at different temperatures before and after thermal resistance test. Pressure = $10 \mathrm{MPa}, S_{\mathrm{v}}=10000 \mathrm{~h}^{-1}$. 

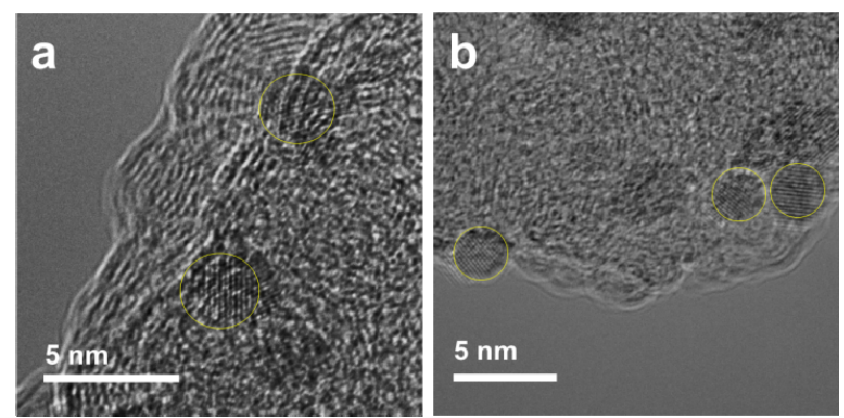

Fig. 8. TEM images of fresh (a) and used (b) Ba-K/Ru-MC catalyst during ammonia synthesis.

\subsection{Comparison of Ba-K/Ru-MC with various Ru and fused Fe catalysts}

The catalytic performance of Ba-K/Ru-MC was compared with those of $\mathrm{Ba}-\mathrm{Ru}-\mathrm{K} / \mathrm{AC}, \mathrm{Ru} / \mathrm{Ba}-\mathrm{MgO}$, and commercialized ZA-5 fused Fe catalysts. These four catalysts were tested together in a four-tube reactor under $400{ }^{\circ} \mathrm{C}$ at various pressures, and the results are presented in Fig. 9. The performances of all the catalysts for ammonia synthesis improved with increasing pressure. Obviously, the semi-embedded catalyst Ba-K/Ru-MC revealed the highest activity, compared with the optimized $\mathrm{Ba}-\mathrm{Ru}-\mathrm{K} / \mathrm{AC}$ and $\mathrm{Ru} / \mathrm{Ba}-\mathrm{MgO}$, that was almost 10 orders higher than that of the commercial $\mathrm{Fe}_{1-x} \mathrm{O}$-based catalyst (ZA-5). The reaction rate over $\mathrm{Ba}-\mathrm{K} / \mathrm{Ru}-\mathrm{MC}$ reaches a maximum (133 $\mathrm{mmol} /(\mathrm{g} \cdot \mathrm{h})$ ) at $10 \mathrm{MPa}$ and $400{ }^{\circ} \mathrm{C}$, whereas the slopes of the reaction rate with pressure for $\mathrm{Ru} / \mathrm{Ba}-\mathrm{MgO}$ and $\mathrm{ZA}-5$ are much smaller than those for Ba-K/Ru-MC and Ba-Ru-K/AC. The increasing trend of the activity with pressure indicates less $\mathrm{H}_{2}$ poisoning in $\mathrm{Ba}-\mathrm{K} / \mathrm{Ru}-\mathrm{MC}$ compared to the other Ru catalysts. This could be explained based on its reversible $\mathrm{H}_{2}$ absorption/desorption capability, which results from the intensive $\mathrm{Ru}-\mathrm{C}$ surface contacts of $\mathrm{Ba}-\mathrm{K} / \mathrm{Ru}-\mathrm{MC}$ [33]. In addition, the $\mathrm{Ba}-\mathrm{K} / \mathrm{Ru}-\mathrm{MC}$ catalyst shows a much higher activity than similar composite catalysts that have been reported in the literature, and a comparison of the activities obtained in this study with

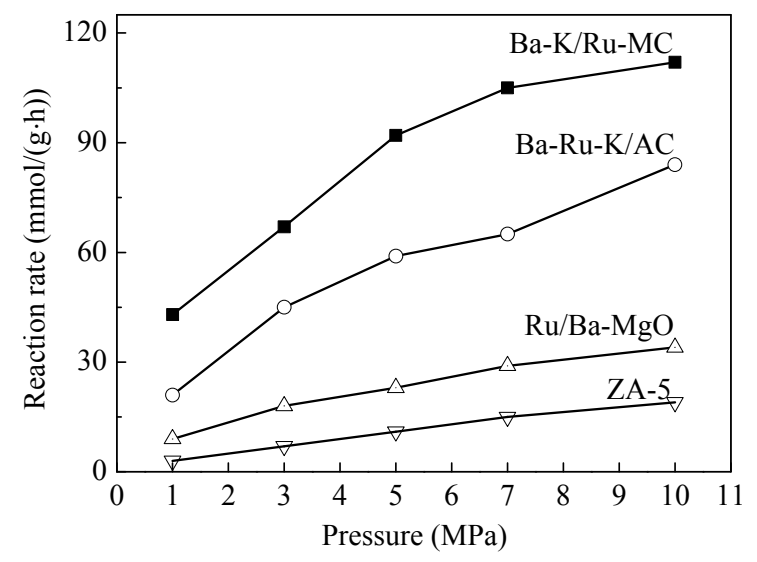

Fig. 9. Reaction rates for ammonia synthesis over various catalysts, measured at $400{ }^{\circ} \mathrm{C}, 10000 \mathrm{~h}^{-1}$, as functions of pressure. the data reported in the literature is presented in Table S2.

\section{Conclusions}

A highly stable and active Ba-K/Ru-MC catalyst for ammonia synthesis with semi-embedded Ru NPs in the size range 1.5-2.5 $\mathrm{nm}$ that were confined in mesoporous $\mathrm{C}$ materials was prepared by a $\mathrm{RuCl}_{3} / \mathrm{SiO}_{2}$-templated approach. The activity of this catalyst is much higher than that of the $\mathrm{Ba}-\mathrm{Ru}-\mathrm{K} / \mathrm{MC}$ catalyst, especially at temperatures below $450{ }^{\circ} \mathrm{C}$. In addition, the Ba-K/Ru-MC catalyst has a higher activity than the AC-supported Ru and commercial Fe catalysts. The high catalytic activity and stability of Ba-K/Ru-MC is attributed to the strong interaction between the $\mathrm{Ru}$ and the mesoporous $\mathrm{C}$ and the high dispersion of the $\mathrm{Ru}$ particles. The specific three-dimensional mesoporous structures may be beneficial for the dispersion of active components and promoters, and the thin and locally graphitized structure of MC can be beneficial for electron transport.

\section{References}

[1] J. A. Pool, E. Lobkovsky, P. J. Chirik, Nature, 2004, 427, 527-530.

[2] K. Honkala, A. Hellman, I. N. Remediakis, A. Loqadottir, A. Carlsson, S. Dahl, C. H. Christensen, J. K. Norskor, Science, 2005, 307, 555-558.

[3] N. Saadatjou, A. Jafari, S. Sahebdelfar, Chem. Eng. Commun., 2015, 202, 420-448.

[4] C. Huo, Q. H. Xia, M. H. Pan, X. Z. Yang, Y. Luo, H. Z. Liu, Chin. J. Catal., 2011, 32, 315-320.

[5] C. F. Xu, L. Ouyang, J. Zhang, B. Zhou, Y. Li, H. Z. Liu, Chin. J. Catal., 2010, 31, 677-682.

[6] G. Q. Feng, G. J. Lan, Y. Li, W. F. Han, H. Z. Liu, Chin. J. Catal., 2012, 33, 1191-1197.

[7] Y. P. Zhou, G. J. Lan, B. Zhou, W. Jiang, W. F. Han, H. Z. Liu, Y. Li, Chin. J. Catal., 2013, 34, 1395-1401.

[8] D. E. Brown, T. Edmonds, R. W. Joyner, J. J. McCarroll, S. R. Tennison, Catal. Lett., 2014, 144, 545-552.

[9] H. S. Zeng, T. Hihara, K. I. Inazu, K. Aika, Catal. Lett., 2001, 76, 193-199.

[10] S. J. Guo, X. L. Pan, H. L. Gao, Z. Q. Yang, J. J. Zhao, X. H. Bao, Chem. Eur. J., 2010, 16, 5379-5384.

[11] J. P. Xiao, X. L. Pan, S. J. Guo, P. J. Ren, X. H. Bao, J. Am. Chem. Soc., 2015, 137, 477-482.

[12] M. Kitano, Y. Inoue, Y. Yamazaki, F. Hayashi, S. Kanbara, S. Matsuishi, T. Yokoyama, S. W. Kim, M. Hara, H. Hosono, Nat. Chem., 2012, 4, 934-940.

[13] Y. Li, G. J. Lan, H. Y. Wang, H. D. Tang, X. H. Yan, H. Z. Liu, Catal. Commun., 2012, 20, 29-35.

[14] G. J. Lan, H. D. Tang, H. Z. Liu, J. Ni, Y. Li, J. Nanosci. Nanotechnol., 2014, 14, 7131-7138.

[15] G. J. Lan, H. D. Tang, Y. P. Zhou, W. F. Han, H. Z. Liu, X. N. Li, Y. Li, ChemCatChem, 2014, 6, 353-360.

[16] F. B. Su, L. Lv, F. Y. Lee, T. Liu, A. I. Cooper, X. S. Zhao, J. Am. Chem. Soc., 2007, 129, 14213-14223.

[17] F. B. Su, F. Y. Lee, L. Lv, J. J. Liu, X. N. Tian, X. S. Zhao, Adv. Funct. Mater., 2007, 17, 1926-1931.

[18] O. Hinrichsen, Catal. Today, 1999, 53, 177-188.

[19] C. J. H. Jacobsen, S. Dahl, P. L. Hansen, E. Tornqvist, L. Jensen, H. Topsoe, D. V. Prip, P. B. Moenshaug, I. Chorkendorff, J. Mol. Catal. A, 


\title{
Graphical Abstract
}

Chin. J. Catal., 2019, 40: 114-123 doi: 10.1016/S1872-2067(18)63192-4

A highly stable and active mesoporous ruthenium catalyst for ammonia synthesis prepared by a $\mathrm{RuCl}_{3} / \mathrm{SiO}_{2}$-templated approach

Yaping Zhou, Yongcheng Ma, Guojun Lan, Haodong Tang, Wenfeng Han, Huazhang Liu, Ying Li *

Zhejiang University of Technology; Sichuan Huadi Construction Engineering Co., Ltd.
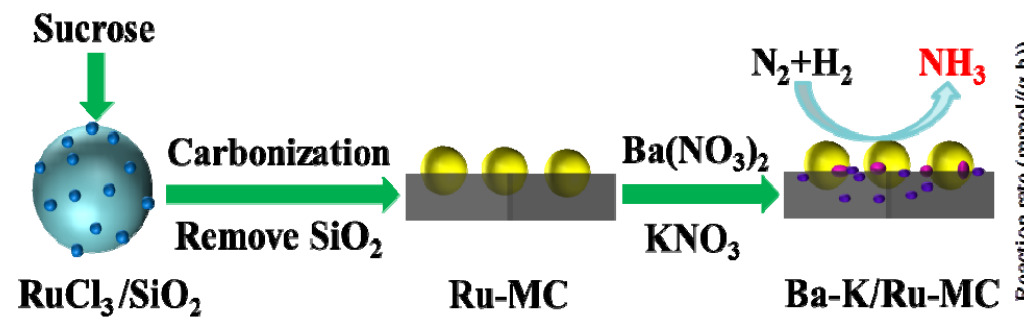

Ru-MC

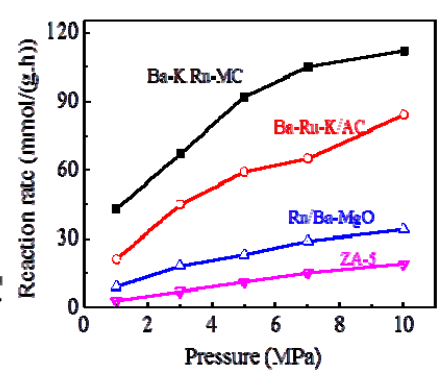

Semi-embedded Ru-MC has stable Ru NPs and strong interaction between Ru and C that promote the catalytic performance for ammonia synthesis.

2000, 163, 19-26.

[20] K. Aika, H. Hori, A. Ozaki, J. Catal., 1972, 27, 424-431.

[21] A. Ozaki, K. Aika, H. Hori, Bull. Chem. Soc. Jpn., 1971, 44, 3216-3216.

[22] J. J. McCarroll, S. R. Tennison, N. P. Wilkinson, USA Patent $4600571,1986$.

[23] W. Rarog-Pilecka, E. Miskiewicz, D. Szmigiel, Z. Kowalczyk, J. Catal., 2005, 231, 11-19.

[24] Y. Li, C. G. Pan, W. F. Han, H. F. Chai, H. Z. Liu, Catal. Today, 2011, 174, 97-105.

[25] L. Jiang, J. W. Yan, R. Xue, L. X. Hao, L. Jiang, G. Q. Sun, B. L. Yi, J. Mater. Sci, 2014, 49, 363-370.

[26] M. J. Xie, J. Yang, J. Y. Liang, X. F. Guo, W. P. Ding, Carbon, 2014, 77, 215-225.
[27] A. C. Ferrari, J. C. Meyer, V. Scardaci, C. Casiraghi, M. Lazzeri, F. Mauri, S. Piscanec, D. Jiang, K. S. Novoselov, S. Roth, A. K. Geim, Phys. Rev. Lett., 2006, 97, 187401-187404.

[28] F. R. Garcia-Garcia, A. Guerrero-Ruiz, I. Rodriguez-Ramos, Top. Catal., 2009, 52, 758-764.

[29] B. Y. Lin, Y. C. Qi, Y. J. Guo, J. X. Lin, J. Ni, Catal. Sci. Technol., 2015, 5, 2829-2838.

[30] Y. D. Li, D. X. Li, G. W. Wang, Catal. Today, 2011, 162, 1-48.

[31] B. Y. Lin, Y. J. Guo, J. D. Lin, J. Ni, J. X. Lin, L. L. Jiang, Y. Wang, Appl. Catal. A, 2017, 541, 1-7.

[32] B. Y. Lin, Y. J. Guo, C. F. Cao, J. Ni, J. X. Lin, L. L. Jiang, Catal. Today, 2018, 316, 230-236.

[33] L. F. Wang, R. T. Yang, J. Phys. Chem. C, 2008, 112, 12486-12494.

\section{以 $\mathrm{RuCl}_{3} / \mathrm{SiO}_{2}$ 为模板制备高性能镶嵌式钉基氨合成催化剂}

\author{
周亚萍 ${ }^{\mathrm{a}, \mathrm{b}}$ ，马永承 ${ }^{\mathrm{a}}$, 蓝国钧 ${ }^{\mathrm{a}}$, 唐浩东 ${ }^{\mathrm{a}}$, 韩文锋 ${ }^{\mathrm{a}}$, 刘化章 ${ }^{\mathrm{a}}$, 李 瑛,

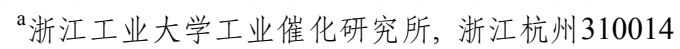 \\ ${ }^{\mathrm{b}}$ 四川省华地建设工程有限责任公司, 四川成都610081
}

摘要: 合成氨工业是国家能源与战略的基石, 是化学工业的支柱产业, 随着国家产业升级与转型, 对合成氨工业的能耗提 出了较为严厉的要求. 钓基催化剂被誉为继铁催化剂后的第二代氨合成催化剂, 与铁催化剂相比, 钉基催化剂在低温和低 压下具有优异的催化性能. 炭材料因具有低成本、高比表面积以及电子传输和热传输等独特性能, 比其它化合物如 $\mathrm{MgO}$, $\mathrm{Al}_{2} \mathrm{O}_{3}$ 和 $\mathrm{BN}$ 等更适合作为 $\mathrm{Ru}$ 催化剂的载体, 而且也是除铁催化剂外唯一已工业化的载体. 虽然炭负载钓催化剂的甲烷化是 不可避免的, 但BP公司使用石墨化碳作为载体成功地解决了这个问题, 并实现了工业化. 为了进一步提高钓基催化剂性能, 对钓炭催化剂的结构设计尤为重要.

中孔炭(MC)孔隙结构发达, 可以为钓纳米粒子的分散提供空间, 从而有效提高金属钉的利用率, 中孔炭负载的钓基催 化剂在合成氨反应中表现出优异的催化性能. 传统负载型钉基催化剂的制备一般采用浸渍法, 虽然可获得高分散的Ru纳 米粒子, 但其只会分布在载体的表面, 因此在反应过程中就容易发生金属纳米粒子的团聚和流失, 大大降低使用寿命. 而 随着新材料制备技术的发展, 对催化剂的设计合成方法的研究也越来越多. 当金属纳米粒子被镶嵌在载体的壁上时, 金属 和载体之间就具有较强的相互作用, 因而可以稳定金属纳米粒子. 
本文通过蔗糖原位炭化法将Ru纳米颗粒半嵌入在炭材料中制备镶嵌式Ru-MC催化剂, 并采用HRTEM, CO化学吸附等 手段系统研究了镶嵌式Ru-MC催化剂与传统浸渍法制备的负载型Ru/MC催化剂之间的差异. 采用等体积浸渍法添加Ba和 K助剂制备催化剂Ba-K/Ru-MC和Ba-Ru-K/MC. 和Ba-Ru-K/MC催化剂相比, Ba-K/Ru-MC催化剂上钓炭相互作用力增强, 不但有效提高了钓催化剂的催化活性, 而且提高了该催化剂的抗甲烷化能力, 从而提高了氨合成条件下催化剂的稳定性和 使用寿命. 采用该方法制备的钉基催化剂在 $400{ }^{\circ} \mathrm{C}, 10000 \mathrm{~h}^{-1}, 10 \mathrm{MPa}$ 和 $\mathrm{H}_{2} / \mathrm{N}_{2}=3.0$ 的反应条件下, 氨合成反应速率可以达 到 $133 \mathrm{mmol} /(\mathrm{g} \cdot \mathrm{h})$, 其性能远高于目前报导的钓基催化剂和传统的熔铁催化剂.

关键词: 中孔炭; 镶嵌式; 钉炭催化剂; 高分散; 氨合成

收稿日期: 2018-09-12. 接受日期: 2018-10-19. 出版日期: 2019-01-05.

*通讯联系人. 电话: (0571)88320766; 传真: (0571)88320259; 电子信箱: liying@zjut.edu.cn

基金来源：国家自然科学基金(20803064); 浙江省自然科学基金(LY17B030010).

本文的电子版全文由Elsevier出版社在ScienceDirect上出版(http://www.sciencedirect.com/science/journal/18722067). 